\title{
Competitive interaction and economic injury level of Urochloa plantaginea in corn hybrids
}

\section{Interação competitiva e nível de dano econômico de papuã em híbridos de milho}

\author{
Leandro Galon ${ }^{*}$ (D), Cinthia Maethê Holz ${ }^{1}$ (D), César Tiago Forte ${ }^{1}$ (D), Felipe Nonemacher ${ }^{1}$ (D), \\ Felipe José Menin Basso' ${ }^{1}$ (D), Luciane Renata Agazzi ${ }^{1}$ (D), Carlos Orestes Santin ${ }^{1}$ (D), \\ Fabio Luis Winter ${ }^{1}$ (D), Josiel Ricardo Toni ${ }^{1}$ (D), Gismael Franciso Perin'
}

\begin{abstract}
Identifying the competitive ability of corn hybrids and the economic injury level (EIL) caused by Urochloa plantaginea is important for the adoption of integrated management of this weed. This work aims to evaluate the interference and EIL of U. plantaginea infesting corn hybrids. Treatments included the corn hybrids Syngenta Status VIP3, Syngenta SX8394 VIP3, Pioneer P1630H, Pioneer 30F53 YH, and Dow 135021, as well as 12 densities of $U$. plantaginea for each hybrid. We used a rectangular hyperbolic model to describe the relationship between corn grain productivity loss and the explanatory variables — plant density (PD), dry mass (DM) of the aerial parts, ground cover (GC), and leaf area (LA). EIL was determined using grain productivity, control cost, corn price, and herbicide efficacy. The rectangular hyperbolic model provides a satisfactory estimate of grain productivity loss regarding the interference of $U$. plantaginea in corn culture. The hybrids Pioneer 30F53 $\mathrm{YH}$ and Pioneer $\mathrm{P} 1630 \mathrm{H}$ presented better competitiveness and higher EIL. Sowing the hybrids Pioneer P1630H, Pioneer 30F53 $\mathrm{YH}$, and Dow 135021 increased EIL, justifying the adoption of control measures for $U$. plantaginea at higher densities.
\end{abstract}

KEYWORDS: Urochloa plantaginea; Zea mays; integrated weed management.
RESUMO: A identificaçáo da habilidade competitiva de híbridos de milho e do nível de dano econômico (NDE) ocasionado pelo papuã (Urochloa plantaginea) torna-se importante para a adoção do manejo integrado dessa planta daninha. Diante disso, objetivou-se com este trabalho avaliar a interferência e o NDE de papuã infestante de híbridos de milho. Os tratamentos foram compostos pelos híbridos de milho Syngenta Status VIP 3, Syngenta SX8394 VIP 3, Pioneer P1630H, Pioneer 30F53 YH e Dow 135021 e 12 densidades de plantas de papuá para cada híbrido. Para descrever a relaçáo entre a perda de produtividade de grãos do milho e as variáveis explicativas densidade de plantas (DP), massa seca da parte aérea (MS), cobertura do solo (CS) e área foliar (AF), usou-se o modelo da hipérbole retangular. A determinação do NDE foi efetuada usando-se a produtividade de grãos, custo de controle, preço do milho e eficiência do herbicida. O modelo da hipérbole retangular estima de modo satisfatório as perdas de produtividade de grãos em função da interferência do papuã na cultura do milho. Os híbridos Pionner 30F53 YH e Pionner P1630H apresentaram melhor competitividade e os maiores NDEs. A semeadura dos híbridos Pioneer P1630H, Pioneer 30F53 YH e Dow 135021 aumenta o NDE, justificando a adoção de medidas de controle em densidades mais elevadas.

PALAVRAS-CHAVE: Urochloa plantaginea; Zea mays; manejo integrado de plantas daninhas. 


\section{INTRODUCTION}

In Brazil, corn is an important cereal since approximately 95 million tons of grains are produced in an area of about 17.7 million hectares (USDA, 2019). This level of production is only possible because of enhanced culture management, associated with the use of hybrids with high productive potential due to genetic improvement (BRITO et al., 2011; SILVA et al., 2011).

Weed management in annual cultures, as is the case for corn, has become indispensable to the production of grains. Losses from weed competition vary from 15 to $85 \%$ (VIDAL et al., 2004; GALON et al., 2008; KOZLOWSKI et al., 2009; BRITO et al., 2011). Among the weeds that affect corn productivity, presenting a high competitive ability for environmental resources, Urochloa plantaginea stands out (VIDAL et al., 2004; GALON et al., 2008). Therefore, it is necessary to understand not only the damage caused by the competition but also its influence resulting from the change in density and/or the culture management strategy adopted (AGOSTINETTO et al., 2010; KHATOUNIAN et al., 2016).

We highlight the chemical method using herbicides to control the weeds infesting a culture for its efficiency, practicality, and low-cost when compared with other control methods (GALON et al., 2018), as it can be used pre- and post-emergence, preferentially during the critical period of competition (GALON et al., 2008; SILVA et al., 2011). However, nowadays, the aim is to have more sustainable production models due to the need for exploring the economic injury level (EIL) to cultures to reduce environmental impacts. This fact shows the necessity of combining technical knowledge with economic factors (AGOSTINETTO et al., 2010).

Knowledge of EIL allows a farmer to verify what density of weeds in competition with corn the culture can tolerate without great losses and, thus, decide for the most appropriate control measure to adopt (MEULEN; CHAUHAN, 2017). Making a decision when the culture is exposed to large populations of weeds is relatively easy and simple. However, when the competition is with small weed populations, it is necessary to calculate the costs of the control used, a fact that makes the decision-making more complex (AGOSTINETTO et al., 2010). The development of efficient strategies for weed management involves studies that use a variation in plants of the culture and weeds (BERES et al., 2010).

Knowledge of the interference and density of weeds that infest corn is an important tool in the adoption of management methods because it lays the foundation for the farmer to decide whether to control or not the species infesting the culture. This work aims to evaluate the interference and EIL of $U$. plantaginea infesting corn culture.

\section{MATERIAL AND METHODS}

The experiment was conducted in the field, in the experimental area of the Universidade Federal da Fronteira Sul (UFFS), Erechim Campus, RS (latitude $27.725269^{\circ} \mathrm{S}$ and longitude $52.294485^{\circ} \mathrm{W}$ ), in a no-till system on straw, in the agricultural year 2016/17. Ground fertility was corrected based on chemical analysis, with the following characteristics: $\mathrm{pH}($ water $)=5.1$; organic matter $=3.0 \%$; clay $=$ $>60 \% ; \mathrm{P}=5.2 \mathrm{mg} \mathrm{dm}^{-3} ; \mathrm{K}=118.0 \mathrm{mg} \mathrm{dm}^{-3} ; \mathrm{Ca}^{2+}=5.5 \mathrm{cmolc}$ $\mathrm{dm}^{-3} ; \mathrm{Mg}^{2+}=3.0 \mathrm{cmolc} \mathrm{dm}^{-3} ; \mathrm{Al}^{3+}=0.3 \mathrm{cmolc} \mathrm{dm}^{-3} ; \mathrm{H}+$ $\mathrm{Al}=7.7 \mathrm{cmolc} \mathrm{dm}^{-3} ;$ CTC effective $=16.6 \mathrm{cmolc} \mathrm{dm}^{-3}$. Other management processes complied with the technical instructions for corn culture (EMYGDIO; ROSA, 2015). The basal chemical fertilization was $327 \mathrm{~kg} \mathrm{ha}^{-1}$ of the N-P-K formula 05-30-15; N was applied on two occasions, at culture stages V5 and V8, at a dose of $90 \mathrm{~kg} \mathrm{ha}^{-1}$ of $\mathrm{N}$ for each stage.

The experimental design adopted was completely randomized, with one repetition. In this research, the different populations of $U$. plantaginea worked as repetitions, providing the necessary variance for statistical analysis using the nonlinear model proposed by COUSENS (1985). Each experimental unit (portion) covered an area of $15 \mathrm{~m}^{2}(5 \times 3 \mathrm{~m})$, sown with six lines of culture, spaced $0.50 \mathrm{~m}$ apart.

The treatments comprised five corn hybrids (Syngenta Status VIP3, Syngenta SX8394 VIP3, Pioneer P1630H, Pioneer 30F53 YH, and Dow 135021) and 12 densities of $U$. plantaginea $(0,14,14,16,32,36,68,78,98,106,126$, and $134 ; 0,8,10,12,26,34,44,68,76,82,82$, and 102; $0,8,12,14,30,38,44,70,90,90,92$, and $112 ; 0,10,14$, $16,24,64,64,76,90,94,146$, and 154; and $0,8,12,18$, $34,46,52,60,84,104,112$, and 142 plants $\mathrm{m}^{-2}$ ) for each corn hybrid evaluated, respectively. Each corn hybrid had 12 plots, and each plot had a different density of $U$. plantaginea. As the area was naturally infested with the weed, the different densities of $U$. plantaginea were established from the soil seed bank, by applying the herbicide tembotrione $\left(100.8 \mathrm{~g} \mathrm{ha}^{-1}\right)$, Soberan ${ }^{\circledR}\left(240 \mathrm{~mL} \mathrm{ha}^{-1}\right)+$ adjuvant Áureo ${ }^{\oplus} 0.5 \%(\mathrm{v} / \mathrm{v})$. The application was made with a precision backpack sprayer, pressurized with $\mathrm{CO}_{2}$ and equipped with four type DG 110.02 nozzles, with a constant pressure of $210 \mathrm{kPa}$ and travel speed of $3.6 \mathrm{~km} \mathrm{~h}^{-1}$, which provided a flow rate of $150 \mathrm{~L} \mathrm{ha}^{-1}$ of herbicide mixture. The densities of $U$. plantaginea, object of this study, were protected with plastic cups in each experimental unit to avoid damage from the herbicide. The herbicide tembotrione was chosen due to its weed control, selectivity for corn culture, and for being non-persistent in soil (RODRIGUES; ALMEIDA, 2011); in this way, the U. plantaginea plants protected with plastic cups did not absorb the herbicide by their root system, and the target populations in each experimental unit were achieved. 
As the $U$. plantaginea originated from the soil seed bank, the establishment of weed density to compete with corn varied, because factors such as infestation, vigor, and moisture, among others, made it difficult to determine the exact number of plants desired for each treatment (experimental unit).

The sowing density of corn hybrids was 3.5 viable seeds per linear meter or 70,000 seeds $\mathrm{ha}^{-1}$, leading to an approximate density of 7.0 plants $\mathrm{m}^{-2}$. Corn hybrids were chosen for their genetic difference and for being the most cultivated by farmers in the region. The corn hybrids involved in the test are intended for producing grains with the following characteristics:

- Syngenta Status VIP3: early cycle, insect-resistant, and herbicide-tolerant.

- Syngenta SX8394 VIP3: early cycle, insect-resistant, and herbicide-tolerant.

- Pioneer P1630H: super-early cycle, insect-resistant, and herbicide-tolerant.

- Pioneer 30F53 YH: early cycle, insect-resistant, and herbicide-tolerant.

- Dow 135021: early cycle, insect-resistant, and herbicide-tolerant.

Plant density (PD), leaf area (LA), ground cover (GC), and dry mass $(\mathrm{DM})$ of the aerial parts of $U$. plantaginea were measured 30 days after the emergence of the culture. The number of $U$. plantaginea plants were counted in two areas of $0.5 \times$ $0.5 \mathrm{~m}\left(0.25 \mathrm{~m}^{2}\right)$ per portion to measure the variable PD. Two evaluators working individually visually determined the GC of $U$. plantaginea, using a percentage scale in which a zero score corresponded to the lack of cover, and a score of 100 represented total GC. A portable leaf area meter (CI-203, BioScience) was used to measure LA; plants were collected in the center of each experimental unit in an area of $0.5 \times 0.5 \mathrm{~m}$ $\left(0.25 \mathrm{~m}^{2}\right)$. After measuring the LA, leaves from $U$. plantaginea plants were placed in kraft paper bags and dried in a forced air convection oven at $60 \pm 5^{\circ} \mathrm{C}$, until uniformity, to determine the DM (stems plus leaves).

The productivity of hybrid corn grains was calculated by ear harvest in a useful area of $3.0 \mathrm{~m}^{2}$ in each experimental unit when the moisture content of the grains was about $20 \%$. After weighing, the moisture content of the grains was measured, and the masses were standardized at $13 \%$ moisture, extrapolating the results to $\mathrm{kg} \mathrm{ha}^{-1}$.

Following the determination of grain productivity, the percentage losses regarding the portions that remained without infestation were calculated, according to Equation 1:

Loss $(\%)=\frac{(\mathrm{Ra}-\mathrm{Rb})}{\mathrm{Ra}} \times 100$

In which: $\mathrm{Ra}$ and $\mathrm{Rb}$ are the corn productivity without or with the presence of $U$. plantaginea, respectively. All hybrids had control checks without the presence of $U$. plantaginea, and Equation 1 was applied to all weed densities.
The values for DM $\left(\mathrm{g} \mathrm{m}^{-2}\right)$, GC (\%), and LA $\left(\mathrm{cm}^{2}\right)$ were multiplied by 100 before the data analysis to avoid the need for a correction factor in the model (AGOSTINETTO et al., 2010).

The relationships among percentage losses of grain productivity concerning the explanatory variables were calculated separately for each corn hybrid, using the nonlinear regression model derived from the rectangular hyperbola proposed by COUSENS (1985), according to Equation 2:

$\mathrm{Lp}=\frac{\left(\mathrm{i}^{*} \mathrm{X}\right)}{\left(\left(1+(\mathrm{i} / \mathrm{a})^{*} \mathrm{X}\right)\right.}$

In which: $\mathrm{Lp}=$ loss of productivity (\%); $\mathrm{X}=\mathrm{PD}, \mathrm{DM}$, $\mathrm{GC}$, or LA of $U$. plantaginea; and $i$ and $a=$ losses of productivity (\%) per unit of $U$. plantaginea plants when the value of the variable is approximately zero or when it tends to infinity, respectively.

Data were adjusted to the model using the PROC NLIN procedure of the computer program SAS (1989). Calculations were done using the Gauss-Newton method, which, by successive iterations, estimates the parameter values in which the sum of squares of deviations of the observations is the minimum compared to the adjusted value.

We adopted the value of the F statistic $(\mathrm{p} \leq 0.05)$ as a criterion for adjusting the data to the model. The acceptance criterion for the adjustment of data to the model was based on the highest value of the coefficient of determination $\left(R^{2}\right)$ and the lowest value of the residual mean square (QMR).

Calculation of the EIL used the estimates for parameter $i$ obtained from Equation 2 (COUSENS, 1985) and the adapted equation of LINDQUIST; KROPFF (1996) - Equation 3:

$$
\mathrm{EIL}=\frac{(\mathrm{Cc})}{\left(\mathrm{R}^{*} \mathrm{P}^{*}(\mathrm{i} / 100)^{*}(\mathrm{H} / 100)\right)}
$$

In which: EIL = economic injury level $\left(\right.$ plants $\left.\mathrm{m}^{-2}\right)$; $C c=$ control cost (herbicide and soil application by tractor, in dollars ha $\left.{ }^{-1}\right) ; R=$ corn grain productivity $\left(\mathrm{kg} \mathrm{ha}^{-1}\right)$; $P=$ corn price (dollars $\mathrm{kg}^{-1}$ of grains); $i=$ loss (\%) of corn productivity per unit of competing plants when the population level approaches zero; and $H=$ level of herbicide efficacy (\%).

Three values were estimated for the variables $C c, R$, $P$, and $H$ (Equation 3). $C c$ was the average price, with the maximum and minimum cost changed by $25 \%$. $R$ was based on the lowest, mean, and highest productivity in Rio Grande do Sul in the last 10 years. $P$ was estimated from the lowest, mean, and highest price for corn paid per $60 \mathrm{~kg}$ sack in the last 10 years. The values for $H$ were established in the order of 80,90 , and $100 \%$ control, with $80 \%$ being the minimum control level considered effective for the weed (OLIVEIRA et al., 2009). In the EIL simulations, we used intermediate values for the variables that were not the object of the calculation. 


\section{RESULTS AND DISCUSSION}

The explanatory variables PD, LA, GC, and DM for $U$. plantaginea, evaluated for productivity loss in the corn hybrids Syngenta Status VIP3, Syngenta SX8394 VIP3, Pioneer P1630H, Pioneer 30F53 YH, and Dow 135021, presented significant $\mathrm{F}$ statistic values (Table 1). In all corn hybrids tested, the rectangular hyperbolic model was adjusted properly to the data, showing average values of $\mathrm{R}^{2}$ for PD, GC, LA, and DM over 0.69 and a low QMR, which characterizes a good fit of the data to the model. CARGNELUTTI FILHO; STORCK (2007), while working with genetic variation, the effect of cultivars, and the heritability of corn hybrids, considered values of $\mathrm{R}^{2}$ between 0.57 and 0.66 moderate to good, which partly corroborates the results found in this study.
The results show that the values estimated for the parameter $i$ tended to be larger for the corn hybrid Syngenta SX8394 VIP3 when compared to the mean values of all variables evaluated - PD, LA, GC, and DM (Table 1). In the same comparison, we found greater competitiveness in the corn hybrids Syngenta Status VIP3, Pioneer P1630H, Pioneer 30F53 YH, and Dow 135021, which presented smaller losses of grain productivity in contrast to the other hybrids. Some studies have evidenced differences in the competitive ability of corn hybrids in the presence of weeds, a fact assigned to several factors, mainly the competition that occurs among the species involved, be it intra- or interspecific (BRITO et al., 2011; SILVA et al., 2011; FARIA et al., 2014).

When comparing the corn hybrids Syngenta Status VIP3, Syngenta SX8394 VIP3, Pioneer P1630H, Pioneer 30F53 $\mathrm{YH}$, and Dow 135021 for the variable PD based on unitary

Table 1. Adjustments obtained with the rectangular hyperbolic model of Cousens (1985) for grain productivity loss due to interference of Urochloa plantaginea with corn hybrids; Syngenta Status VIP3, Syngenta SX8394 VIP3, Pioneer P1630H, Pioneer $30 F 53 \mathrm{YH}$, and Dow 135021 in answer to the relative explanatory variables. UFFS, Erechim, 2017

\begin{tabular}{|c|c|c|c|c|c|}
\hline \multirow{2}{*}{ Relative explanatory variables } & \multicolumn{2}{|c|}{ Parameters ${ }^{1}$} & \multirow{2}{*}{$\mathbf{R}^{2}$} & \multirow{2}{*}{ QMR } & \multirow{2}{*}{$\mathbf{F}$} \\
\hline & 1 & $a$ & & & \\
\hline \multicolumn{6}{|l|}{ Plant population } \\
\hline Syngenta Status VIP3 & 2.99 & 79.76 & 0.80 & 28.26 & $488.14^{*}$ \\
\hline Syngenta SX8394 VIP3 & 6.43 & 51.49 & 0.74 & 32.74 & $283.87 *$ \\
\hline Pioneer P1630H & 2.35 & 59.90 & 0.79 & 44.98 & $173.95^{*}$ \\
\hline Pioneer $30 F 53 \mathrm{YH}$ & 1.54 & 76.85 & 0.88 & 85.79 & $110.18^{*}$ \\
\hline Dow 135021 & 2.88 & 62.65 & 0.72 & 85.19 & $116.25^{*}$ \\
\hline \multicolumn{6}{|l|}{ Ground cover } \\
\hline Syngenta Status VIP3 & 0.12 & 76.68 & 0.88 & 39.76 & $345.47^{*}$ \\
\hline Syngenta SX8394 VIP3 & 0.25 & 51.33 & 0.69 & 33.26 & $279.36^{*}$ \\
\hline Pioneer $\mathrm{P} 1630 \mathrm{H}$ & 0.35 & 49.47 & 0.68 & 22.72 & $326.33^{*}$ \\
\hline Pioneer $30 F 53$ YH & 0.06 & 81.35 & 0.53 & 123.70 & $74.90^{*}$ \\
\hline Dow 135021 & 0.16 & 59.44 & 0.80 & 111.00 & 82.71 * \\
\hline \multicolumn{6}{|l|}{ Leaf area } \\
\hline Syngenta Status VIP3 & 1.43 & 47.82 & 0.52 & 285.00 & $43.90^{*}$ \\
\hline Syngenta SX8394 VIP3 & 2.49 & 40.81 & 0.86 & 93.70 & $177.74^{*}$ \\
\hline Pioneer $\mathrm{P} 1630 \mathrm{H}$ & 2.15 & 41.91 & 0.59 & 60.18 & $121.02 *$ \\
\hline Pioneer 30F53 YH & 1.99 & 39.17 & 0.87 & 357.90 & $42.87^{*}$ \\
\hline Dow 135021 & 4.32 & 58.00 & 0.76 & 632.70 & $7.96^{*}$ \\
\hline \multicolumn{6}{|l|}{ Dry mass } \\
\hline Syngenta Status VIP3 & 0.05 & 75.91 & 0.76 & 81.76 & $165.44^{*}$ \\
\hline Syngenta SX8394 VIP3 & 0.12 & 47.04 & 0.82 & 43.25 & $198.87^{*}$ \\
\hline Pioneer $\mathrm{P} 1630 \mathrm{H}$ & 0.09 & 47.41 & 0.61 & 30.80 & $202.59 *$ \\
\hline Pioneer 30F53 YH & 0.02 & 75.33 & 0.72 & 75.33 & $96.09 *$ \\
\hline Dow 135021 & 0.08 & 44.14 & 0.54 & 33.63 & 117.41 * \\
\hline
\end{tabular}

${ }^{1} i$ and $a$ : productivity losses (\%) by unity of Urochloa plantaginea when the value of the variable approaches zero or tends to infinity, respectively; *Significant for $\mathrm{p} \leq 0.05$. 
loss (i), we identified productivity losses of $2.99,6.43,2.35$, 1.54 , and $2.88 \%$, respectively (Table 1 ). WILLIAMS et al. (2008) attributed the differences in corn hybrid competition to a bigger canopy (LA) and plant height, resulting in better light interception efficiency, leading to greater weed suppression. The competition imposed by the genetic material is a potential strategy for integrated weed management in current control programs (JHA et al., 2017).

The hybrid Dow 135021 showed grain productivity loss of $46.6 \%$ when comparing the mean results of parameter $i$, obtained by the rectangular hyperbolic equation, for this hybrid with the others for the variable LA (Table 1). The hybrids Syngenta Status VIP3, Syngenta SX8394 VIP3, Pioneer $\mathrm{P} 1630 \mathrm{H}$, and Pioneer 30F53 YH presented lower productivity losses $(1.43,2.49,2.15$, and $1.99 \%)$ when compared with Dow 135021. We can infer that the degree of weed competition in relation to corn is influenced by the LA, that is, the greater the LA of the weed per relative unit, the more competitive it will be compared to the culture showing bigger loss of productivity. According to the increase in proportion and LA of $U$. plantaginea, the competitive ability of the weed becomes greater than that of the sorghum culture (GALON et al., 2018); this study shows that $U$. plantaginea is highly competitive with corn cultures. Another work conducted by SILVA et al. (2011), which analyzed the competition of 18 species of weeds with corn, showed a reduction in LA, DM, root system, and corn grain yield.

The results for corn hybrid productivity loss regarding the percentage of GC and DM are similar to that observed in PD (Table 1), as the hybrids Syngenta SX8394 VIP3 and Pioneer $30 \mathrm{~F} 53 \mathrm{YH}$ were less competitive and presented the highest productivity losses. The increase in $U$. plantaginea LA, $\mathrm{GC}$, and DM is directly related to $\mathrm{Lp}$, thus explaining the similarity in productivity losses among the variables evaluated, when taking into account the parameter $i$ of each of them. Among the factors attached to this interference imposed by the weeds are mainly the competition for light and nutrients (WILLIAMS et al., 2008; JHA et al., 2017).

DIELEMAN et al. (1995) used the parameter $i$ to compare the competitiveness among species, finding different values for the corn hybrids Syngenta Status VIP3, Syngenta SX8394 VIP3, Pioneer P1630H, Pioneer 30F53 $\mathrm{YH}$, and Dow 135021 in the explanatory variables tested (Table 1). Comparison among the hybrids, considering the parameter $i$ for the average of the four explanatory variables (PD, GC, LA, or DM), showed that the general order of competitiveness was: Pioneer $30 \mathrm{~F} 53 \mathrm{YH}>$ Syngenta Status VIP3 > Pioneer P1630H > Dow 135021 $>$ Syngenta SX8394 VIP3. The differences between results for the hybrids are largely due to the best use of space or resources available in the environment, or the effect of a high standard error on the determination of the parameter $i$, which can be assigned to the variability associated with field experimentation and/or the culture phenotypic plasticity (DIELEMAN et al., 1995).

We underline that the hybrid Pioneer 30F53 YH presented the lowest productivity loss in the average parameter $i$ evaluated for the variables PD, LA, GC, and DM; however, one of the hybrids showed the lowest grain productivity $\left(6.8 \mathrm{t} \mathrm{ha}^{-1}\right)$ when compared to the others. The hybrids had distinct productive potential, and we identified that the productivity of cultures without the presence of $U$. plantaginea was: $7.73,10.18,8.63,6.81$, and 8.34 t ha ${ }^{-1}$ for Syngenta Status VIP3, Syngenta SX8394 VIP3, Pioneer P1630H, Pioneer 30F53 YH, and Dow 135021, respectively. Therefore, this study showed that less productive materials presented higher competitive ability with $U$. plantaginea, considering the parameter $i$, quite possibly due to a smaller need for allocating resources in other organs of the plant rather than the ear. Leaf architecture and plant arrangement are factors that influence the absorption of solar radiation and the performance of photosynthesis, elements that have a direct relationship with the development of ears and grains (BRITO et al., 2011; SILVA et al., 2011; FARIA et al., 2014).

The estimates of the parameter $a$, regardless of the explanatory variable, were all lower than $100 \%$ (Table 1), showing that it was possible to accurately simulate the maximum productivity losses of corn grains with the populations of $U$. plantaginea used. We also emphasized that, if the conditions of ground fertility, water availability, and lightness are appropriate, the higher the productive potential of the cultures, the smaller the daily percentage loss caused by a determined species of weed (KALSING; VIDAL, 2013).

Comparison of the explanatory variables for all corn hybrids tested generally showed better adjustment to the model in the order $\mathrm{PD}>\mathrm{GC}>\mathrm{DM}>\mathrm{LA}$, considering the largest mean values for $\mathrm{R}^{2}$ and $\mathrm{F}$ and the smallest mean values of QMR (Table 1), highlighting that $\mathrm{Lp}$ can be used instead of the other variables to estimate corn grain productivity losses.

We simulated EIL values using the $U$. plantaginea explanatory variable $\mathrm{PD}$, as this variable presented the best adjustment to the model, is the most used in experiments with this purpose (VIDAL et al., 2010; KALSING; VIDAL, 2013), and also for being easy to determine in the field.

Determining the density that exceeds the EIL can lead to a successful implementation of management systems for $U$. plantaginea infesting corn culture. Thus, we identified that the hybrids Pioneer P1630H, Pioneer 30F53 YH, and Dow 135021 presented larger EIL values in the simulations performed, ranging from 1.07 to 5.49 plants $\mathrm{m}^{-2}$ (Figs. 1, 2, 3 and 4). The hybrid Syngenta SX8394 VIP3 presented the lowest EIL values, varying from 0.48 to 1.31 plants $\mathrm{m}^{-2}$. The hybrid Syngenta Status VIP3 showed an intermediate level of EIL compared with the others. 
When comparing the average for corn hybrids, we found a difference in EIL of $71.9 \%$ between the lowest $\left(3.74 \mathrm{t} \mathrm{ha}^{-1}\right)$ and highest $\left(5.20 \mathrm{t} \mathrm{ha}^{-1}\right)$ grain productivity (Fig. 1). Thereby, the greater the productive potential of the corn hybrid, the smaller the density of $U$. plantaginea plants that equals the EIL, making advantageous the adoption of measures for weed control. VIDAL et al. (2004) claimed that the EIL of $U$. plantaginea in irrigated corn rises as the price of the culture decreases, increasing the control cost; an elevation in the corn price reduces the impact of control cost for this weed, leading to a higher economic return from the culture.

The average result for all the hybrids evaluated, from the highest to the lowest price paid per corn sack, had a variation of 2.7 times in the EIL value (Fig. 2). Therefore, the lower the price paid per corn sack, the higher the density of

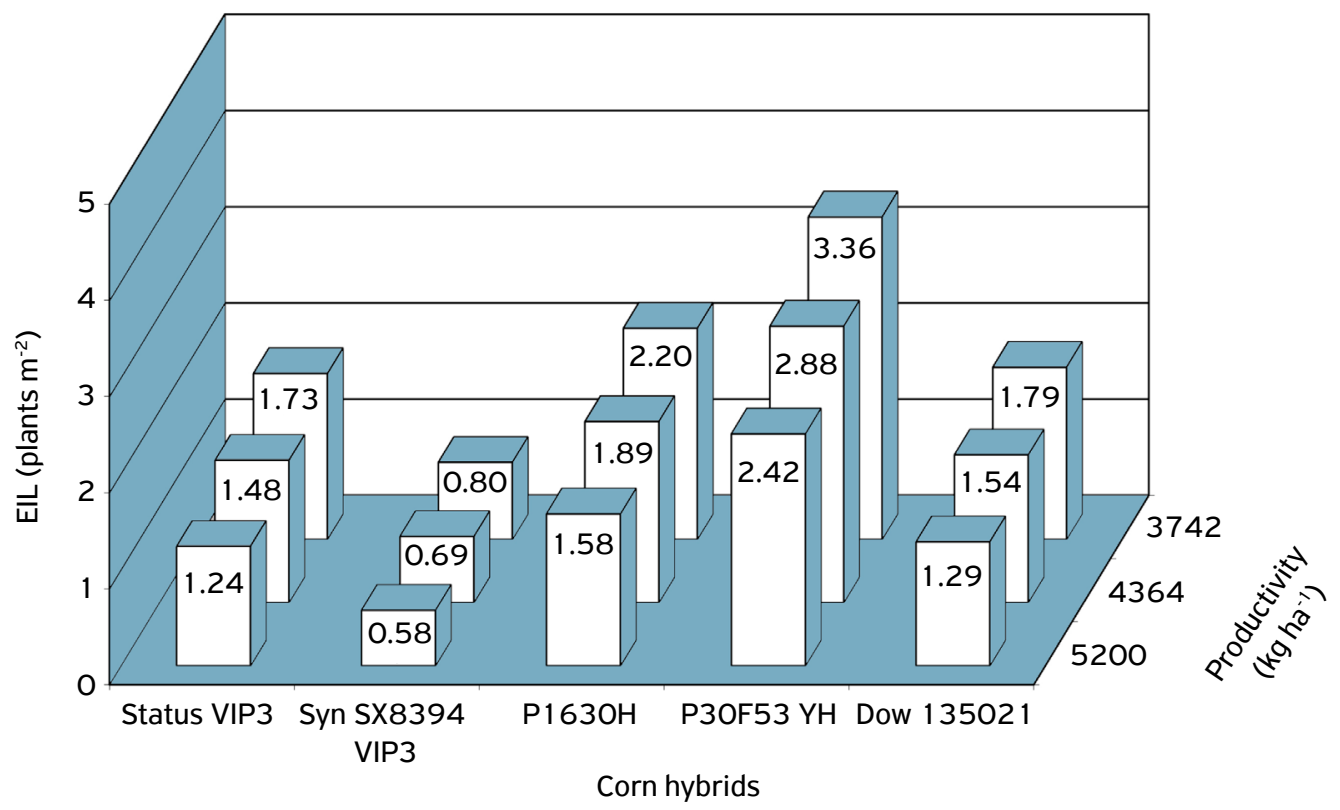

Figure 1. Economic injury level (EIL) in corn according to grain productivity and Urochloa plantaginea and hybrid plant populations.

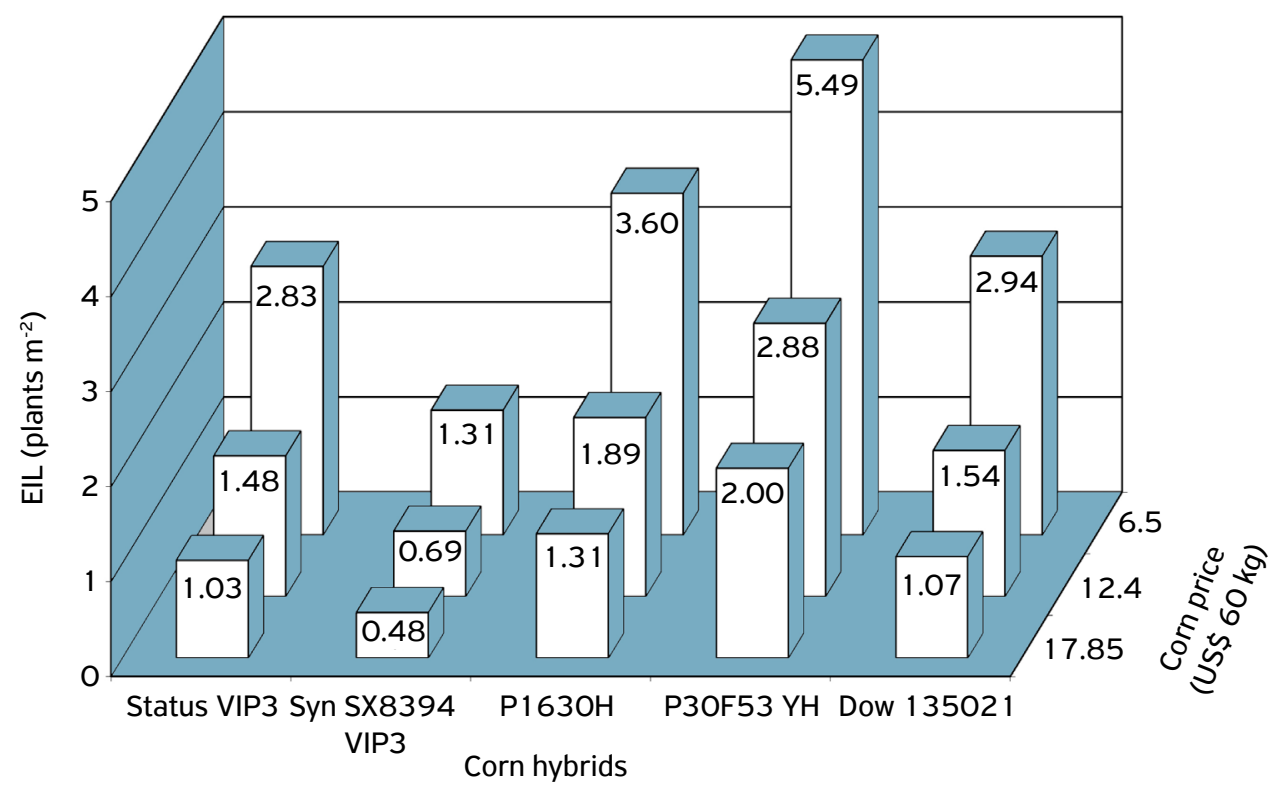

Figure 2. Economic injury level (EIL) in corn according to the price of the culture and Urochloa plantaginea and hybrid plant populations. 
$U$. plantaginea necessary to exceed the EIL, so the control method can be advantageous.

Regarding the cost of controlling $U$. plantaginea in all hybrids, we found that the minimum value was approximately $60 \%$ smaller than the maximum one. Consequently, the higher the cost of the control method, the greater the EIL, and the more the $U$. plantaginea plants $\mathrm{m}^{-2}$ necessary to justify these control measures (Fig. 3). The use of EIL as a tool for weed control must be associated with good agricultural practices for managing the corn, since its implementation is only justified in tillages that use crop rotation, proper plant arrangement, more competitive hybrids, appropriate sowing periods, and correction of soil fertility, among others.

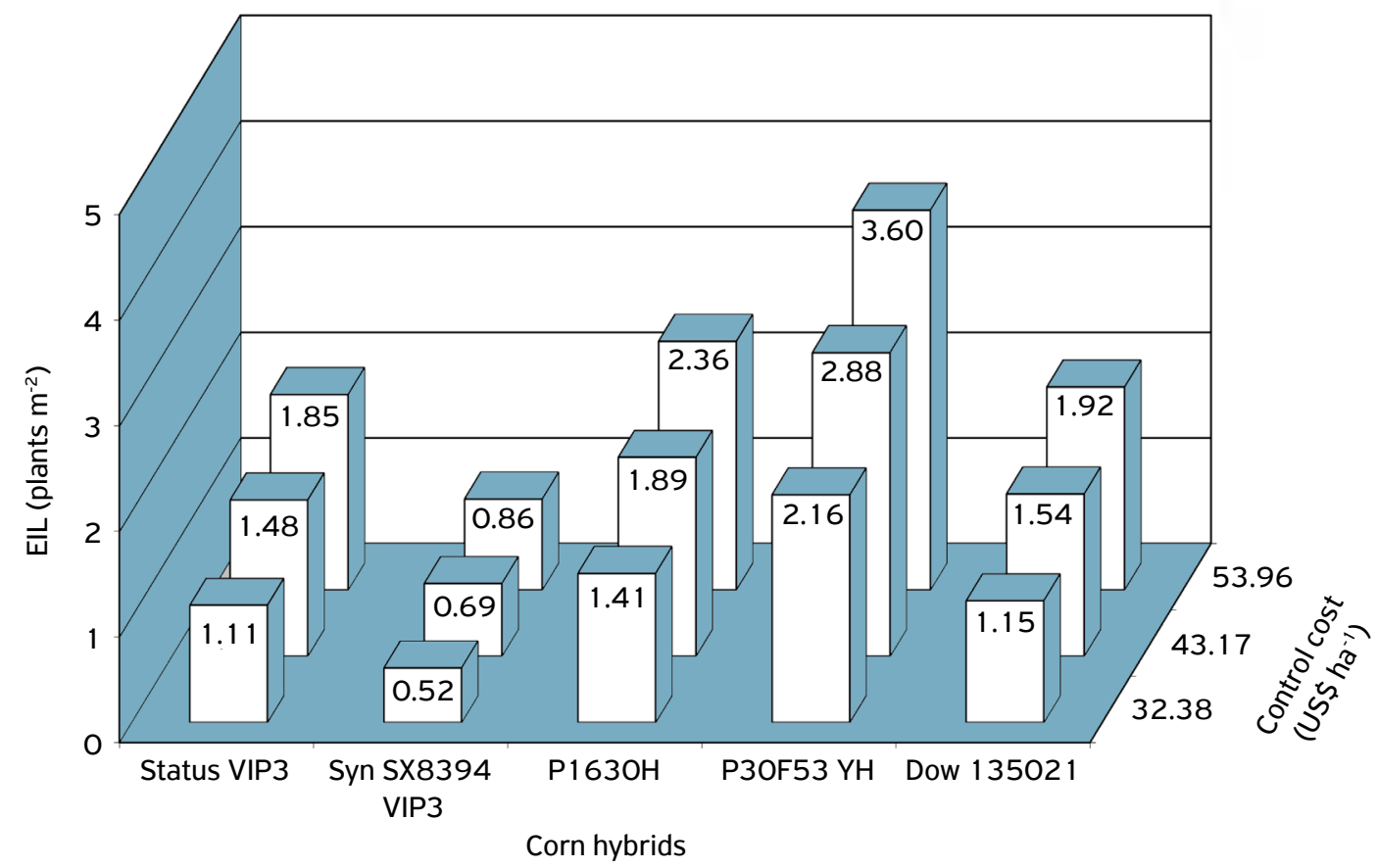

Figure 3. Economic injury level (EIL) in corn according to control cost and Urochloa plantaginea and hybrid plant populations.

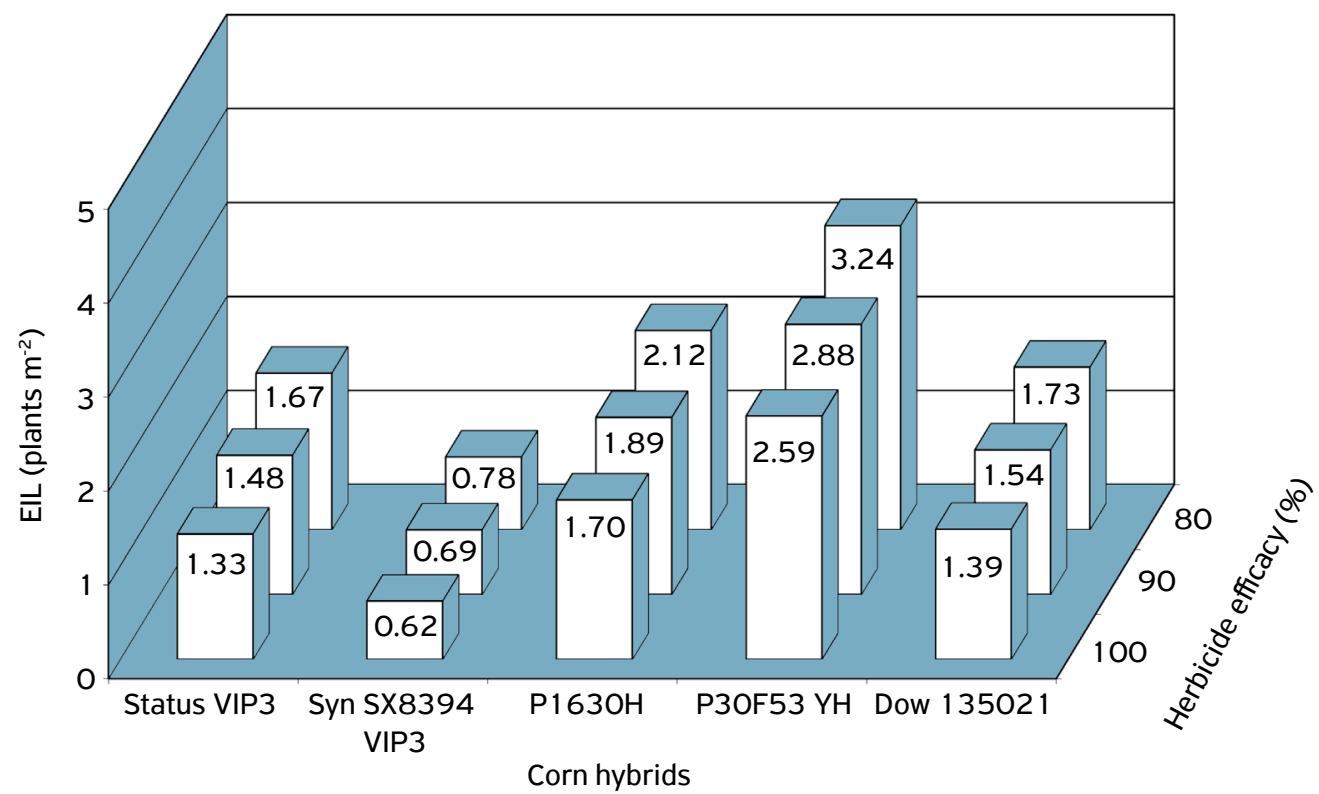

Figure 4. Economic injury level (EIL) in corn according to herbicide efficacy and Urochloa plantaginea and hybrid plant populations. 
With respect to the efficacy of the chemical control method using herbicide, we verified that a variation in average efficacy between 80 and $100 \%$ results in alterations to the EIL of approximately 10 and $11 \%$, respectively (Fig. 4). Thus, the level of control influences the EIL, and the better the herbicide efficacy, the lower the EIL (smaller number of $U$. plantaginea plants $\mathrm{m}^{-2}$ necessary to adopt control measures).

\section{CONCLUSIONS}

The rectangular hyperbolic nonlinear regression model properly estimates corn grain productivity losses in the presence of $U$. plantaginea populations. The corn hybrids Pioneer $\mathrm{P} 1630 \mathrm{H}$ and Pioneer $30 \mathrm{~F} 53 \mathrm{YH}$ present, in general, better competitive ability with $U$. plantaginea than the others.
The highest EIL values vary from 1.07 to 5.49 plants $\mathrm{m}^{-2}$ for the hybrids Pioneer P1630H and Pioneer 30F53 YH, which showed the best competitiveness with $U$. plantaginea. EIL decreases as grain productivity, price per corn sack, and herbicide efficacy increase and with the reduction in the cost of controlling $U$. plantaginea, justifying the adoption of control measures in smaller weed populations.

\section{ACKNOWLEDGMENTS}

The authors thank Conselho Nacional de Desenvolvimento Científico e Tecnológico (CNPq) (Process 307291/2016-2 and 406221/2016-2), Fundação de Amparo à Pesquisa do Estado do Rio Grande do Sul (FAPERGS) (Process 842-25.51/134), and Financiadora de Estudos e Projetos (FINEP) (Process 0752/13) for the financial support for the research and the concessions of scholarships.

| | | | | | | | | | | | | | | | | | | | | | | | | | | | | | | | | | | | | | | | | | | | | | | | | | | | | | | | | | | | | | | | | | | | | | | | | | | | | | | | | | | | | | | | | | | | | | | | | | | | | | | | | | | | | | | | | | | | | | | | | | | | | | | | | | | | | | | | | | | | | | | | | | | | | | | | | | | | | | | | | | | | | | | | | | | | | | | | | | | | | | | | | | | | | | | | | | | | | | | | | | | | | | | | | | | | | |

\section{REFERENCES}

AGOSTINETTO, D.; GALON, L.; SILVA, J.M.B.V.; TIRONI, S.P.; ANDRES, A. 2010. Interferência e nível de dano econômico de capim-arroz sobre o arroz em função do arranjo de plantas da cultura. Planta Daninha, Viçosa, v.28, n.esp., p.993-1003, 2010. http://dx.doi.org/10.1590/SO100-83582010000500007

BERES, B.L.; HARKER, K.N.; CLAYTON, G.W.; BREMER, E. Weedcompetitive ability of spring and winter cereals in the northern great plains. Weed Technology, Lawrence, v.24, n.2, p. 108-116, 2010. https://doi.org/10.1614/WT-D-09-00036.

BRITO, A.H.; PINHO, V.R.G.; SANTOS, A.O.; SANTOS, S. Reação de híbridos de milho e comparação de métodos para avaliação da cercosporiose e mancha branca. Tropical Plant Pathology, Brasília, v.36, n. 1, p.035-041, 201 1. http://dx.doi.org/10.1590/ S1982-56762011000100005

CARGNELUTTI FILHO, A.; STORCK, L. Estatísticas de avaliação da precisão experimental em ensaios de cultivares de milho. Pesquisa Agropecuária Brasileira, Brasília, v.42, n.1, p.17-24, 2007. http://dx.doi.org/10.1590/S0100-204X2007000100003

COUSENS, R. An empirical model relating crop yield to weed and crop density and a statistical comparison with other models. The Journal of Agricultural Science, Cambridge, v.105, n.3, p.513-521, 1985. https://doi.org/10.1017/ SOO2 1859600059396

DIELEMAN, A.; HAMILL, A.S.; WEISE, S.F.; SWANTON, C.J. Empirical models of pigweed (Amaranthus spp.) interference in soybean (Glycine max). Weed Science, Lawrence, v.43, n.4, p.612-618, 1995. https://www.jstor.org/stable/4045820
EMYGDIO, B.M.; ROSA, A.P.S.A. Indicações técnicas para o cultivo de milho e de sorgo no Rio Grande do Sul: Safras 2015/2016 e 2016/2017. In: REUNIÃO TÉCNICA ANUAL DE MILHO, 60., 2015; REUNIÃO TÉCNICA ANUAL DE SORGO, 43., 2015, Getúlio Vargas/RS. Brasília, DF: Embrapa, 2015. 127p.

FARIA, R.M.; BARROS, R.E.; TUFFI SANTOS, L.D. Weed interference on growth and yield of transgenic maize. Planta Daninha, Viçosa, v.32, n.3, p.515-520, 2014. http://dx.doi.org/10.1590/ S0100-83582014000300007

GALON, L.; PINTO, J.J.O.; ROCHA, A.A.; CONCENÇO, G.; SILVA, A.F.; ASPIAZÚ, I.; FERREIRA, E.A.; FRANÇA, A.C.; FERREIRA, F.A.; AGOSTINETTO, D.; PINHO, C.F. Períodos de interferência de Brachiaria plantaginea na cultura do milho na região Sul do Rio Grande do Sul. Planta Daninha, Viçosa, v.26, n.4, p.779-788. http://dx.doi.org/10.1590/S0100-83582008000400009

GALON, L.; SANTIN, C.O.; ANDRES, A.; BASSO, F.J.M.; NONEMACHER, F.; AGAZZI, L.R.; SILVA, A.F.; HOLZ, C.M.; FERNANDES, F.F. Habilidade competitiva de cultivares de sorgo sacarino com plantas daninhas. Planta Daninha, Viçosa, v.36, e018173689, 2018. http://dx.doi. org/10.1590/s0100-83582018360100053

JHA, P.; KUMAR, V.; GODARA, R.K.; CHAUHAN, B.S. Weed management using crop competition in the United States: $A$ review. Crop Protection, Oxford, v.95, n.1, p.31-37, 2017. https://doi.org/10.1016/j.cropro.2016.06.021

KALSING, A.; VIDAL, R.A. Nível crítico de dano de papuã em feijãocomum. Planta Daninha, Viçosa, v.31, n.4, p.843-50, 2013. http://dx.doi.org/10.1590/SO100-83582013000400010. 
KHATOUNIAN, C.A.; PASSINI, T.; PENHA, L.A.O.; OLIVEIRA, D.A.M. Seed production of Urochloa plantaginea (Link) R. Webster infesting maize and in pure stands. Revista Brasileira de Agroecologia, Porto Alegre, v. 11, n.4, p.281-286, 2016.

KOZLOWSKI, L.A.; KOEHLER, H.S.; PITELLI, R.A. Épocas e extensões do período de convivência das plantas daninhas interferindo na produtividade da cultura do milho (Zea mays). Planta Daninha, Viçosa, v.27, n.3, p.481-490, 2009. http://dx.doi.org/10.1590/ s0 $100-83582009000300008$

LINDQUIST J. L.; KROPFF M. J. Application of an ecophysiological model for irrigated rice (Oryza sativa) - Echinochloa competition. Weed Science, Lawrence, v.44, n. 1, p.52-56, 1996. https://www. jstor.org/stable/4045782

MEULEN, A.; CHAUHAN, B.S. A review of weed management in wheat using crop competition. Crop Protection, Oxford, v.95, n. 1 , p.38-44, 2017. https://doi.org/10.1016/j.cropro.2016.08.004

OLIVEIRA, A.R.; FREITAS, S.P.; VIEIRA, H.D. Controle de Commelina benghalensis, $C$. erecta, Tripogandra diuretica na cultura do café. Planta Daninha, Viçosa, v.27, n.4, p.823-830, 2009. http:// dx.doi.org/10.1590/SO100-8358200900040002 1

RODRIGUES, B.N.; ALMEIDA, F.S. Guia de herbicidas. 6. ed. Londrina: Grafmarke, $2011.697 p$.
SAS. Institute Statistical Analysis System. User's guide: version 6.4 ed. Cary: SAS Institute. 1989.

SILVA, P.S.L.; SILVA, P.I.B.; SILVA, K.M.B.; OLIVEIRA, V.R.; PONTES FILHO, F.S.T. Corn growth and yield in competition with weeds. Planta Daninha, Viçosa, v.29, n.4, p.793-802, 201 1. http:// dx.doi.org/10.1590/SO100-83582011000400009

USDA. Department of Agriculture. 2019. Available from: https:// www.fsis.usda.gov/wps/portal/fsis/topics/international-affairs/ importing-products. Access on: Feb. 212019.

VIDAL, R.A.; KALSING, A.; GHEREKHLOO, J. Interferência e nível de dano econômico de Brachiaria plantagiea e Ipomoea na cultura do feijão comum. Ciência Rural, Santa Maria, v.40, n.8, p.1675-1681, 2010. http://dx.doi.org/10.1590/ s0103-84782010000800001

VIDAL, R.A.; SPADER, V.; FLECK, N.G.; MEROTTO JUNIOR, A. Nível de dano econômico de Brachiaria plantaginea na cultura de milho irrigado. Planta Daninha, Viçosa, v.22, n. 1, p.63-69, 2004. http://dx.doi.org/10.1590/S0100-83582004000100008

WILLIAMS, M.M.; BOYDSTON, R.A.; DAVIS, A.S. Crop competitive ability contributes to herbicide performance in sweet corn. Weed Research, Oxford, v.48, n.1, p.58-67, 2008. https://doi. org/10.1111/j.1365-3180.2008.00602.x 